\title{
Student internships and employment opportunities after graduation: A field experiment
}

\author{
By Stijn Baert ${ }^{\mathrm{a}}$, Brecht Neyt ${ }^{\mathrm{b}}$, Thomas Siedler ${ }^{\mathrm{c}}$, Ilse Tobback ${ }^{\mathrm{d}}$, Dieter Verhaest ${ }^{\mathrm{e}, *}$ \\ ${ }^{a}$ Ghent University, University of Antwerp, Université catholique de Louvain, IZA, GLO, and IMISCOE, Sint-Pietersplein 6, 9000 Ghent, Belgium \\ ${ }^{\mathrm{b}}$ Ghent University, Sint-Pietersplein 6, 9000 Ghent, Belgium \\ ${ }^{c}$ Universität Potsdam, Berlin School of Economics (BSE) and IZA, August-Bebel-Straße, 8914482 Potsdam, Germany \\ ${ }^{\mathrm{d}}$ KU Leuven, Naamsestraat 69 - bus 3565, 3000 Leuven, Belgium \\ ${ }^{\mathrm{e}} \mathrm{KU}$ Leuven, Ghent University, and GLO, Warmoesberg 26, 1000 Brussels, Belgium
}

\section{A R T I C L E I N F O}

\begin{tabular}{l}
\hline$J E L:$ \\
I21 \\
J23 \\
J24 \\
C93 \\
Keywords: \\
Internship \\
Hiring \\
Field experiment \\
Human capital \\
Signalling
\end{tabular}

\begin{abstract}
A B S T R A C T
Internships during tertiary education have become substantially more common over the past decades in many industrialised countries. This study examines the impact of a voluntary intra-curricular internship experience during university studies on the probability of being invited to a job interview. To estimate a causal relationship, we conducted a randomised field experiment in which we sent 1248 fictitious, but realistic, resumes to real job openings. We find that applicants with internship experience have, on average, a $12.6 \%$ higher probability of being invited to a job interview.
\end{abstract}

\section{Introduction}

Over the past decades, there has been a growing interest in internships, both by students looking for an internship and by universities or schools integrating them in their curricula or promoting them as extracurricular activities (Margaryan, Saniter, Schumann, \& Siedler, 2020). To illustrate this, while the number of US university graduates with internship experience was lower than $3 \%$ in 1980, this had increased to around 75\% by 2000 (Cook, Parker \& Pettijohn, 2004). Likewise, according to the Eurobarometer survey conducted in 2013, about $45 \%$ of all EU citizens aged 18-35 reported undertaking an internship (European Commission, 2013).

Graduates indicate future labour market success to be the prime motivation to participate in internships (Krawietz, Müßig-Trapp, \& Willige, 2006). Indeed, a growing body of evidence shows a positive relationship between internship participation during tertiary education and favourable labour market outcomes after graduation. However, as reviewed in the next section, these results are potentially biased because of the non-experimental nature of most of these studies. This would be the case when students who do an internship differ from students who do not in terms of characteristics that are not controlled for but which also affect labour market success. For example, students who choose to participate in an internship may be more motivated, hard-working, risk-averse, and/or ambitious than other students. In the present study, we deal with this problem by conducting a randomised field experiment in which pairs of fictitious applications of Belgian graduates (one with and one without internship experience) are sent to real job openings. By monitoring the subsequent callback, we are able to assess whether internships causally affect the likelihood of receiving an invitation to a job interview.

To the best of our knowledge, only one other study has already adopted experimental methods to examine the effect of internship experience on labour market success. Conducting a correspondence test in which resumes were sent to job vacancies in business-related industries in the United States, ${ }^{1}$ Nunley, Pugh, Romero, and Seals (2016) found that applicants with internship experience were $14.3 \%$ more

\footnotetext{
* Corresponding author.

E-mail addresses: Stijn.Baert@UGent.be (B.S. Baert), Brecht.Neyt@UGent.be (B. Neyt), Thomas.Siedler@uni-potsdam.de, thomas.siedler@uni-potsdam.de (T. Siedler), Ilse.Tobback@kuleuven.be (I. Tobback), Dieter.Verhaest@kuleuven.be (D. Verhaest).

1 The authors randomly assigned a 3-month, industry-relevant extra-curricular internship to a portion of these resumes.
} 
Table 1

Literature review.

\begin{tabular}{|c|c|c|c|c|c|}
\hline $\begin{array}{l}(1) \\
\text { Study }\end{array}$ & $\begin{array}{l}(2) \\
\text { Country }\end{array}$ & $\begin{array}{l}\text { (3) } \\
\text { Type of internship }\end{array}$ & $\begin{array}{l}\text { (4) } \\
\text { Labour market outcome variable(s) }\end{array}$ & $\begin{array}{l}\text { (5) } \\
\text { Main results: empirical relation between } \\
\text { (3) and (4) }\end{array}$ & $\begin{array}{l}\text { (6) } \\
\text { Approach to deal with endogeneity } \\
\text { problem }\end{array}$ \\
\hline $\begin{array}{l}\text { Callanan and } \\
\text { Benzing (2004). }\end{array}$ & US. & $\begin{array}{l}\text { Voluntary or } \\
\text { mandatory (not } \\
\text { specified) intra- } \\
\text { curricular. }\end{array}$ & $\begin{array}{l}\text { Securing a career-orientated job } \\
\text { and experiencing a good personal } \\
\text { fit with the job. }\end{array}$ & $\begin{array}{l}\text { Positive association with securing a } \\
\text { career-orientated job. }\end{array}$ & None. \\
\hline $\begin{array}{l}\text { Gault et al. } \\
\text { (2000). }\end{array}$ & US. & $\begin{array}{l}\text { Voluntary or } \\
\text { mandatory (not } \\
\text { specified) intra- } \\
\text { curricular. }\end{array}$ & $\begin{array}{l}\text { Ease of finding first job, annual } \\
\text { wage, satisfaction with co-workers } \\
\text { and supervisor, and overall job } \\
\text { satisfaction. }\end{array}$ & $\begin{array}{l}\text { Positive effect on ease of finding first } \\
\text { job, annual wage, and overall job } \\
\text { satisfaction. }\end{array}$ & $\begin{array}{l}\text { Matching (on: age, years of work } \\
\text { experience, GPA, major area of } \\
\text { study, and gender). }\end{array}$ \\
\hline $\begin{array}{l}\text { Gault et al. } \\
\text { (2010). }\end{array}$ & US. & $\begin{array}{l}\text { Voluntary or } \\
\text { mandatory (not } \\
\text { specified) intra- } \\
\text { curricular. }\end{array}$ & Job and wage offers. & $\begin{array}{l}\text { Positive association with job offers. } \\
\text { Positive association with wage offers, } \\
\text { but only for high performing interns. }\end{array}$ & None. \\
\hline $\begin{array}{l}\text { Klein and Weiss } \\
\text { (2011). }\end{array}$ & Germany. & $\begin{array}{l}\text { Mandatory intra- } \\
\text { curricular. }\end{array}$ & $\begin{array}{l}\text { Ease of finding first job, job match, } \\
\text { and annual wage. }\end{array}$ & No effect. & Propensity score matching. \\
\hline $\begin{array}{l}\text { Knouse, Tanner } \\
\text { and Harris } \\
\text { (1999). }\end{array}$ & US. & $\begin{array}{l}\text { Voluntary intra- } \\
\text { curricular. }\end{array}$ & $\begin{array}{l}\text { Employment status at graduation } \\
\text { and employment status six months } \\
\text { after graduating. }\end{array}$ & $\begin{array}{l}\text { Positive association with having a job at } \\
\text { graduation. }\end{array}$ & None. \\
\hline $\begin{array}{l}\text { Margaryan et al. } \\
\text { (2020). }\end{array}$ & Germany. & $\begin{array}{l}\text { Mandatory and } \\
\text { voluntary intra- } \\
\text { curricular. }\end{array}$ & Monthly wage. & $\begin{array}{l}\text { Positive effect, especially in (i) areas of } \\
\text { study with a weak labour market } \\
\text { orientation and (ii) humanities and } \\
\text { social sciences. }\end{array}$ & $\begin{array}{l}\text { IV approach (instruments: } \\
\text { introduction and abolition of } \\
\text { mandatory internships). }\end{array}$ \\
\hline $\begin{array}{l}\text { Neumark and } \\
\text { Rothstein } \\
\text { (2007). }\end{array}$ & US. & Not specified. & $\begin{array}{l}\text { Hourly earnings, hourly wage, and } \\
\text { employment status. }\end{array}$ & $\begin{array}{l}\text { Positive association with having a job, } \\
\text { but only for males. Positive association } \\
\text { with hourly earnings and hourly wage, } \\
\text { but only for females. }\end{array}$ & Control for observable factors. \\
\hline $\begin{array}{l}\text { Nunley et al. } \\
\text { (2016). }\end{array}$ & US. & $\begin{array}{l}\text { Voluntary extra- } \\
\text { curricular. }\end{array}$ & Interview requests. & Positive effect. & Experimental design. \\
\hline $\begin{array}{l}\text { Pasewark, } \\
\text { Strawser and } \\
\text { Wilkerson } \\
\text { (1989). }\end{array}$ & US. & Not specified. & Interview process success. $^{\mathrm{a}}$ & $\begin{array}{l}\text { Positive association with obtaining an } \\
\text { off-campus office visit with a 'Big Eight' } \\
\text { firm. }\end{array}$ & Control for observable factors. \\
\hline $\begin{array}{l}\text { Rigsby, Addy, } \\
\text { Herring and } \\
\text { Polledo (2013). }\end{array}$ & US. & $\begin{array}{l}\text { Voluntary intra- } \\
\text { curricular. }\end{array}$ & Job offers. & Positive association. & Control for observable factors. \\
\hline $\begin{array}{l}\text { Siegel and Rigsby } \\
\text { (1988). }\end{array}$ & US. & $\begin{array}{l}\text { Voluntary intra- } \\
\text { curricular. }\end{array}$ & $\begin{array}{l}\text { Performance evaluation and speed } \\
\text { to promotion. }\end{array}$ & Positive association. & None. \\
\hline Silva et al. (2016). & Portugal. & $\begin{array}{l}\text { Voluntary and } \\
\text { mandatory intra- } \\
\text { curricular. }\end{array}$ & Ease of finding first job. & Positive association. & None. \\
\hline Silva et al. (2018). & Portugal. & $\begin{array}{l}\text { Voluntary and } \\
\text { mandatory intra- } \\
\text { curricular. }\end{array}$ & Graduate employment. & Positive association. & None. \\
\hline Taylor (1988). & US. & $\begin{array}{l}\text { Voluntary intra- } \\
\text { curricular. }\end{array}$ & $\begin{array}{l}\text { Job offers, starting wage, extrinsic } \\
\text { satisfaction (pay and geographic } \\
\text { location), and position satisfaction. }\end{array}$ & $\begin{array}{l}\text { Positive association with starting wage } \\
\text { and extrinsic job satisfaction. }\end{array}$ & None. \\
\hline $\begin{array}{l}\text { Verhaest and } \\
\text { Baert (2018). }\end{array}$ & Belgium. & $\begin{array}{l}\text { Mandatory intra- } \\
\text { curricular. }\end{array}$ & $\begin{array}{l}\text { Ease of finding first job and ease of } \\
\text { finding first job at educational } \\
\text { level. }\end{array}$ & No effect. & $\begin{array}{l}\text { Discrete choice model with } \\
\text { exclusion restriction (instruments: } \\
\text { distance to supply of programmes } \\
\text { with internships). }\end{array}$ \\
\hline Weiss et al. (2014) & Germany. & $\begin{array}{l}\text { Mandatory and } \\
\text { voluntary intra- and } \\
\text { extra-curricular. }\end{array}$ & $\begin{array}{l}\text { Job search duration, probability of } \\
\text { working in service class positions, } \\
\text { and hourly wage }\end{array}$ & $\begin{array}{l}\text { Positive effect of voluntary internships } \\
\text { on integration into the labour market. } \\
\text { No effect of mandatory internships. }\end{array}$ & Propensity score matching. \\
\hline
\end{tabular}

Notes. The following abbreviations are used: US (United States), GPA (Grade Point Average), and IV (Instrumental Variable).

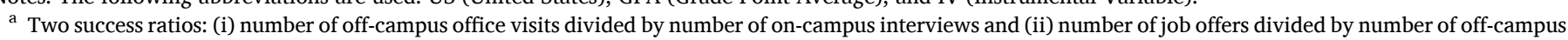
office visits.

likely to be invited to a job interview. This effect was stronger for non-business majors and applicants with high academic ability, measured by the inclusion of applicants' grade point averages. Given that the internship took place 4 years before the fictitious application, the authors interpreted their results to be more likely explained by signalling than by human capital theory.

We investigate the effect of internships on hiring chances in a comparable experimental setting. Besides being among the few studies that investigate the effects of internships in a causal way and being the first European study to address this by means of a correspondence experiment, we contribute to the literature in three further ways. First, contrary to Nunley et al. (2016) who study extra-curricular internships, we consider intra-curricular internships that are offered as elective courses at universities. ${ }^{2}$ Knowing whether voluntary intra-curricular internships are beneficial for students is particularly relevant for universities and faculties that consider integrating internships in their curricula. Second, while Nunley et al. (2016) solely focus on the effect of internships on hiring chances in business-related industries, we include a broader set of occupations and vacancies to increase the generalisability of the results. Third, to the best of our knowledge, we are the first to explore the

\footnotetext{
${ }^{2}$ As these internships serve as a substitute for an elective in-class course, the treatment group in our study has obtained the same number of credits as the control group.
} 
mechanisms explaining the relationship between internships and labour market success. On the one hand, to explore the empirical importance of signalling effects in this respect, we alternate applications with extensive and limited resumes. We argue that finding a relatively stronger treatment effect for internship experience when combined with a limited resume would be consistent with this theory. On the other hand, to explore the importance of human capital theory in this context, we alternate resumes with and without additional hard or soft skills and explore whether internships are a substitute for other forms of human capital.

The remainder of this study is structured as follows. In the next section, we summarise the empirical literature on internships and labour market outcomes and outline relevant theories in this context. Then, we describe our experimental design along with the institutional setting in which our research took place. Subsequently, in Section 4, we present our results. Section 5 concludes with a discussion.

\section{Empirical evidence and theoretical mechanisms}

The previous literature on the relationship between internships during tertiary education and labour market outcomes is summarised schematically in Table 1 . The table includes research on both intra- and extra-curricular internships. Since our focus is on the comparison between graduates with internship experience during studies and those without such an experience but otherwise identical in terms of education and work experience, ${ }^{3}$ we exclude studies that compare post-graduation internship experience with graduates who immediately enter the labour market with a standard labour market contract. ${ }^{4}$ Among the 16 studies in Table 1, 14 find a positive association between internship experience and favourable labour market outcomes, such as employment opportunities, wages, job satisfaction, and job status. However, this pattern is different when confined to those studies that account for non-random selection in internships by relying on (quasi-)experimental methods. Apart from the correspondence experiment study by Nunley et al. (2016), five articles use matching techniques (Gault, Leach, \& Duey, 2010; Klein \& Weiss, 2011; Weiss, Klein, \& Grauenhorst, 2014), or an instrumental variable approach (Margaryan et al., 2020; Verhaest \& Baert, 2018). Out of these five studies, two do not find a clear positive effect of internship experience during studies on labour market success after graduation. Hence, the empirical evidence to date is mixed and inconclusive.

Despite this empirical evidence not being fully conclusive, most (economic) theoretical frameworks predict internship experience to heighten the labour market chances of graduates. First, in line with human capital theory (Becker, 1964), internships allow students to increase both their social and professional skills (Chen, Hu, Wang, \& Chen, 2011; Divine, Linrud, Miller, \& Holton Wilson, 2007). For the latter, this is more likely to be achieved by putting into practice the theoretical knowledge learned in class (Divine et al., 2007; Gault, Redington, \& Schlager, 2000), by obtaining occupation-specific skills, by acquiring more general skills such as time management skills (Mihail, 2006), or by learning job acquisition skills (Divine et al., 2007; Gault et al., 2000). Second, signalling theory (Spence, 1973) states that students who choose to do an internship signal to potential future employers that they are highly motivated, hard-working, and/or ambitious. In addition, successful completion of an internship may signal more occupation-specific talents and abilities. Third, students may benefit from internship experience by using it as a probationary period in which they find out for themselves whether they are suited to a job or occupation (Cook et al., 2004). This argument is consistent with the matching theory framework (Jovanovic, 1979), which states that match

\footnotetext{
${ }^{3}$ Except for one alternative elective course that students who did not opt for an internship had to follow (see below).

${ }^{4}$ See, for example, Cerulli-Harms (2017) and Holford (2017).
}

quality is an experience good. Fourth, in line with models of on-the-job screening (Stiglitz, 1975), also employers may use internships as a probationary period (Divine et al., 2007; Morrow, 1995): by being evaluated and cultivated as potential future employees, internships may thus serve as a stepping stone to a regular job with the same firm (Margaryan et al., 2020). Finally, social network theory (Granovetter, 1973) argues that students with internship experience have an enlarged professional network and are more aware of potential labour market opportunities, which in turn could improve hiring chances with other employers (Gault et al., 2000; Zopiatis, 2007).

As the fictitious applicants in a correspondence experiment apply for the same types of jobs outside their network, only signalling and human capital mechanisms may explain a non-zero treatment effect of internship experience on hiring chances in our study. ${ }^{5}$ We explore the relative importance of the signalling and human capital theory by deliberately introducing small variations in the resumes. First, we alternate between extended and more limited versions of the resumes to analyse the importance of signalling. We assume and argue that a more extended resume, in which the graduate, amongst other things, indicates being eager to get the job, is another way of signalling a high level of motivation and ambition. A more extended resume may thus, at least partly, serve as a substitute for an internship experience in case internships signal similar characteristics. If so, we expect the treatment effect of internship experience to be more pronounced when combined with a more limited resume. Second, to explore the importance of human capital theory as a potential explanation, we add variations of additional hard and soft skills, measured by participation in additional extracurricular courses. These courses focus on the acquisition of skills that are often considered to be acquired through internship training as well, such as corporate communication skills or time management skills. If so, we expect the treatment effect of the internship to be the most pronounced for candidates without these additional courses.

The relative importance of the various channels may also depend on the type of internship that is considered. As we focus on voluntary intracurricular internships, which substitute part of the in-class instruction time for on-the-job learning (see below), the human capital channel may be less important than for extra-curricular internships, in which students participate during holiday periods or after graduation. Moreover, the signal of motivation may be less pronounced since these interns need to give up less free time in comparison to extra-curricular interns. ${ }^{6}$ Still, their effects may be stronger in comparison to mandatory intracurricular internships, as the latter are less likely to signal being motivated or ambitious. While the literature review is not entirely conclusive with respect to these predictions concerning the relative effects of alternative types of internships (see Table 1), three out of four former (quasi-)experimental studies that i.a. focussed on mandatory internships did indeed not find evidence for a positive effect on labour market success (Klein \& Weiss, 2011; Verhaest \& Baert, 2018; Weiss et al., 2014).

\section{Experiment}

To investigate the impact of student internships on the probability of being invited to a job interview, we conduct a randomised field

\footnotetext{
${ }^{5}$ Stated otherwise, explanations in terms of social network theory or screening theory cannot be relevant in our setting because the internship experiences are fictitious; therefore, building network ties or using internships as a screening device are not possible.

${ }^{6}$ Cerulli-Harms (2017) argues that extra-curricular internships that are undertaken after graduation are likely to signal problems in finding a regular job. This argument makes sense when the comparison is with individuals who immediately start in a regular job; it makes less sense when the comparison is of individuals that are, apart from their internships participation, identical in terms of work experience.
} 
experiment which builds on the correspondence experimentation framework of Bertrand and Mullainathan (2004). In the following subsections, we discuss the experimentation framework, the experimental identities, the resume templates, the randomisation procedure, the employer responses, the variation in characteristics of the tested vacancies, the resulting data, and the limitations of our experimental approach.

\subsection{Correspondence experimentation framework}

Correspondence experiments have been applied extensively to investigate illegal hiring discrimination, such as ethnic and gender discrimination (Baert, 2018; Neumark, 2018). Within this type of experiment, pairs of fictitious job applications are sent to real job openings. These applicants differ only by the tested characteristic-in our case, a 3-month unpaid voluntary internship experience during the master studies - which is randomly assigned to these applications. The correspondence experimentation framework is considered the golden standard to identify discrimination in the labour market for two reasons. First, the method enables us to detach employer discrimination from supply-side determinants of labour market outcomes (Pager, 2007; Riach \& Rich, 2002). Second, selection based on unobservables is not a concern, as all information available to the employer is controlled by the researchers (Pager, 2007; Riach \& Rich, 2002).

Given these methodological strengths, an emerging literature also relies on correspondence experiments to investigate the recruitment behaviour of employers with respect to various attributes of job seekers based on which unequal treatment is not forbidden by law. In particular, several studies have used this method to study the causal impact on hiring chances of treatments related to a person's labour market career history, such as unemployment duration (Baert \& Verhaest, 2019; Eriksson \& Rooth, 2014; Kroft, Lange, \& Notowidigdo, 2013) or student employment (Baert, Rotsaert, Verhaest, \& Omey, 2016). The use of this methodology for testing the impact of a person's educational career on hiring chances is yet more limited. Along with the study by Nunley et al. (2016) on firm internships, other examples are publications studying the impact of the value of various post-secondary education qualifications (Deming, Yuchtman, Abulafi, Goldin, \& Katz, 2016; Verhaest, Bogaert, Dereymaeker, Mestdagh, \& Baert, 2018) or university reputation (Drydakis, 2016).

In our extension of the framework of Bertrand and Mullainathan (2004), we introduced both within-pair and between-pair randomised candidate characteristics. More concretely, student internship was assigned randomly within each pair of fictitious applications. Other characteristics, such as gender, resume length, and additional skills, were assigned randomly between pairs of fictitious applications to investigate potential heterogeneity in the effect of student internship on the likelihood of receiving a job invitation.

\subsection{Experimental identities}

The experiment was conducted from November 2015 to April 2016. We sent pairs of fictitious applications to real vacancies in Flanders, the northern, Dutch-speaking part of Belgium. One application was from an applicant with an unpaid voluntary internship experience during the master studies and another was from an applicant without this experience. Both applicants obtained a master's degree at a university in June 2015 and had been searching for a job since then. ${ }^{7}$

Graduates from Flemish universities may have participated in three different types of internships during their tertiary education. Historically, mandatory internships or work placements that are an integral part of the curriculum have been the most substantial. They are included

\footnotetext{
${ }^{7}$ About $96.1 \%$ of the Flemish graduates find a job within a year after graduation (VDAB 2018).
}

in a broad range of fields of study and programmes, and their cumulative duration ranges from just a couple of weeks to several months (Verhaest \& Baert, 2018). Nowadays, universities also offer voluntary internships, either as an extra-curricular activity under supervision of the university or, for some programmes, as an elective course that serves as a substitute for an in-class course. In our study, we focus on intra-curricular internships as an elective course for two main reasons. First of all, given the lack of an identical counterfactual applicant (i.e. a graduate from the same programme but without internship experience), correspondence experiments are less suited to investigate the labour market effects of mandatory internships and work placements. Second, by focussing on intra-curricular internships, we differentiate from and complement the study of Nunley et al. (2016).

For the fictitious applications sent, we thus selected master's programmes that offer the option to participate in an internship as an elective course only. Hence, there exists no variation in mandatory internships during these programmes that might potentially bias our estimates. In addition, we only selected programmes from Ghent University and KU Leuven, the two major universities in Flanders. These universities are comparable in reputation. ${ }^{8}$ Moreover, given that the full Flemish territory and the Brussels-Capital Region is reachable within a reasonable commuting time from either Ghent or Leuven, this allows us to apply for vacant jobs across this region. Our selection criteria resulted in 16 master's programmes: three in humanities and social sciences at Ghent University (communication science; economics; and law), eight in exact sciences at Ghent University (biology; bioscience engineering; chemistry; electronics: information and communication technology (ICT); geography; geology; mathematics; and industrial sciences), three in humanities and social sciences at KU Leuven (business economics; business engineering; and economics), and four in exact sciences at $\mathrm{KU}$ Leuven (biology and biotechnology; bioscience engineering; civil engineering; nanoscience, nanotechnology, and nano-engineering).

\subsection{Resume pair templates}

For each pair of applications, we created two resume and motivation letter templates, Type A and Type B, each being in line with the general requirements for a starter job. While both types of applications were equivalent with regard to all crucial characteristics, they differed on a number of inessential features and layout to avoid detection.

All applicants were assumed to be single and living in Ghent (upon graduation from Ghent University) or Leuven (upon graduation from KU Leuven). Along with the information related to educational career, we added the following characteristics to the resume: a common Flemishsounding name, a fictitious postal address (an existing street name in a middle-class neighbourhood was used, but a non-existing house number was indicated), a telephone number and an email address (from major providers), a birthdate, ${ }^{9}$ Belgian nationality, comparable language (Dutch, French, and English) and computer skills, and a driving licence. The motivation letters mentioned that the job applicant (i) had found the vacancy in the database of the Public Employment Agency of Flanders (i. e. the region's main job search channel; Baert, Cockx, Gheyle, \& Vandamme, 2015) and (ii) was looking forward to a job interview. To avoid employers detecting our experimental setup, a variety of common

\footnotetext{
${ }^{8}$ In the Academic Ranking of World Universities (Shanghai ranking; ARWU) of 2017, Ghent University was placed 69th, and KU Leuven 90th. In the QS World University Rankings (QS), Ghent University was placed 125th, and KU Leuven 71st. In the Times Higher Education World University Rankings (THE) of 2017, Ghent University was placed 107th, and KU Leuven 47th.

${ }^{9}$ As all candidates were assumed to have obtained their degree without interruption or delay, the candidates' age was the same within each pair of applications.
} 
terminology was used for the different motivation letters. ${ }^{10}$ The resume and motivation letter templates are available upon request.

\subsection{Vacancy selection and randomisation procedure}

Between November 2015 and April 2016, vacancies for jobs requiring a master's degree within one of the 16 considered programmes were selected from the database of the Public Employment Agency in Flanders. We only focussed on vacancies for jobs in Flanders and the Brussels-Capital Region. Moreover, we only selected vacancies for starter jobs, which are defined as vacancies for which work experience is not an essential condition. We applied to no more than one vacancy from each employer to limit the burden on the employers and to avoid detection of the experiment. In total, 624 vacancies were selected, resulting in a total of $1248(=624 \times 2)$ applications. Of these vacancies, 240 were in the field of humanities, and 384 vacancies were in the field of exact sciences.

While some more recent large-scale experiments sent out up to around 10,000 applications (Deming et al., 2016; Kroft et al., 2013), our sample size is equivalent to or even above the sample sizes adopted in most of the correspondence experiments that are published in well-established journals (for an overview, see Baert, 2018). Moreover, while not focusing on the same treatment, several of these experiments relying on smaller samples focus on related characteristics of one's educational career and did find statistically significant effects (Baert \& Vujić, 2018; Drydakis, 2016; Verhaest et al., 2018). Finally, additional calculations, reported in Appendix A1 and based on the method proposed by Ioannidis, Stanley, and Doucouliagos (2017), show that the statistical power to detect a main effect that is equivalent to the one found by Nunley et al. (2016) is $78.4 \%$ in combination with a statistical significance level of $5 \%$. Not only is this is close to the rule-of-thumb level of $80 \%$ power, it also largely exceeds median power levels realised in most subfields in economics (see Ioannidis et al., 2017).

Within each pair of applications, we randomly assigned the student internship to either the Type A or Type B template. Apart from mentioning the participation in an internship in a company in the motivation letter, we added the following information to the resume: the organisation where the internship took place, ${ }^{11}$ the internship duration, and the position of the intern. ${ }^{12}$ The intra-curricular character of the internship was either mentioned explicitly (Type B CV's) ${ }^{13}$ or signalled indirectly by adding the internship information as an additional characteristic of the diploma (Type A CV's). The internship took place in the master's year of the applicant's education and lasted 3 months. We

\footnotetext{
$\overline{10}$ Note also that internship experience is an uncontested ground for unequal treatment in recruitment (as opposed to, for example, ethnic background). Therefore, it is unlikely that employers would expect to be tested with respect to this treatment.

11 "Claessens NV", a fictitious company name, where "Claessens" is a regular family name and "NV" is the (Dutch) abbreviation of "naamloze vennootschap" (limited liability company), was chosen to prevent signalling through a company's reputation. When checked on the internet, the company name gave various hits, so that recruiters could not relate it to a particular place where the internship took place.

${ }^{12}$ This position was a position as a junior marketeer (programme of communication science); junior economist (economics); junior company lawyer (law); junior biologist (biology); junior engineer (bioscience engineering, electronics: ICT, industrial sciences, bioscience engineering, civil engineering and nanoscience, nanotechnology, and nano-engineering); junior chemist (chemistry); junior geographer (geography); junior geologist (geology); junior mathematician (mathematics); junior accountant (business economics); junior planner (business engineering); and junior biotechnologist (biology and biotechnology).

${ }^{13}$ The internship was then included within the CV panel listing the candidate's educational career, explicitly mentioning "as an elective course within the education program."
}

decided to disclose a 3-month internship duration to simulate a relevant and representative labour market situation. ${ }^{14}$ As a consequence of this within-pair randomisation of the internship experience, the small differences between the Type A and Type B templates mentioned in Section 3.3 could not bias our results.

In addition to this within-pair randomisation of the internship experience, we randomly assigned other candidate characteristics between the candidate pairs to study potential heterogeneity in the internship effect by these characteristics. So, these latter characteristics were equal at the pair level but differed randomly between pairs. More concretely, first, we alternated between male and female candidate pairs. Second, aiming at differentiating between signalling and human capital as possible underlying mechanisms of an internship effect, we alternated between limited and extensive resumes. Besides the elements mentioned in Section 3.3, the extensive resumes mentioned the following candidate assets: (i) favourable personality traits (Type A candidates with an extensive resume described themselves as 'highlymotivated, well-organised, social, and eager to learn', Type B applicants as 'flexible, enthusiastic, precise, and social'); (ii) sports hobbies (soccer for male Type A applicants, volleyball for female Type A applicants, and fitness and tennis for Type B applicants); and (iii) social engagement (student union membership and youth movement activities for Type A and Type B applicants, respectively). Finally, we alternated between candidate pairs with additional hard skills, additional soft skills, and no such additional skills. Candidates with additional hard skills mentioned two additional credits gathered at university (in corporate communication and business administration for Type A candidates, and in English business communication and financial and cost price reporting in companies for Type B candidates). Candidates with additional softs skills mentioned participation in two additional night school courses: time management and effective and efficient meetings (Type A applicants) or project management and assertiveness (Type B applicants). For each of the selected Master's programmes, we thus generated a total of 24 pairs of resumes, resulting from two combinations of CV templates and internship conditions, ${ }^{15}$ two gender conditions, two resume length conditions and three skill conditions.

\subsection{Responses from employer side}

To each selected vacancy, we assigned one of the 24 pairs of applications matching the Master's program requirements of the job. ${ }^{16}$ These two applications were sent in an alternating order, via email and with 12 to $36 \mathrm{~h}$ in between submissions. Subsequently, we registered the responses from the employers' side via telephone voicemail and email. Importantly, these responses did not indicate some discovery of our experiment. The exact content of each response was documented and is available upon request. After receiving a positive response, we replied to the employers as soon as possible by means of an email in which the offer was turned down. This should have minimised the inconvenience for the employers. Reactions later than 30 days after application are treated as censored and assumed to be negative. The outcome variable of our analyses is equal to 1 if the applicant received an invitation to a job interview, and 0 otherwise.

\footnotetext{
${ }^{14}$ A voluntary intra-curricular internship of three months usually represents (and substitutes an elective in-class course of) six ECTS credits. The minimum duration of an intra-curricular internship is four (in the case of an elective of three ECTS credits) or six weeks (in the case of an elective of six ECTS credits). 15 Either a Type A resume with internship experience that is paired with a Type B resume without internship experience, or a Type A resume without internship experience that is paired with a Type B resume with internship experience.

${ }^{16}$ Given this relatively low number of pairs, the CVs used were constructed manually and not by means of using a randomisation tool such as the one introduced in Lahey and Beasley (2016).
} 
Table 2

Data description.

\begin{tabular}{|c|c|c|c|}
\hline (1) & $(2)$ & (3) & (4) \\
\hline Variable & Description & Mean & SD \\
\hline \multicolumn{4}{|l|}{ A. Treatment } \\
\hline Internship & 1 if the candidate reveals a voluntary intra-curricular firm internship during university, 0 otherwise & 0.500 & - \\
\hline \multicolumn{4}{|l|}{ B. Candidate characteristics } \\
\hline Female & 1 if the candidate is female, 0 otherwise & 0.500 & - \\
\hline Male & 1 if the candidate is male, 0 otherwise & 0.500 & - \\
\hline Extended resume & 1 if the candidate applies with an extended resume, 0 otherwise & 0.500 & - \\
\hline Limited resume & 1 if the candidate applies with a limited resume, 0 otherwise & 0.500 & - \\
\hline Additional skills: hard & 1 if the candidate mentions two additional credits gathered at university, 0 otherwise & 0.333 & - \\
\hline Additional skills: soft & 1 if the candidate mentions two additional night school courses, 0 otherwise & 0.333 & - \\
\hline Additional skills: none & 1 if the candidate mentions no additional credits or courses, 0 otherwise & 0.333 & - \\
\hline Humanities and social sciences & 1 if the candidate holds a master's degree in humanities and social sciences, 0 otherwise & 0.385 & - \\
\hline Exact sciences & 1 if the candidate holds a master's degree in exact sciences, 0 otherwise & 0.615 & - \\
\hline \multicolumn{4}{|l|}{ C. Vacancy characteristics } \\
\hline Median vacancy duration & $\begin{array}{l}\text { Median vacancy duration in days for all vacancies in the occupation (in database Public Employment Agency of Flanders) } \\
\text { in } 2015\end{array}$ & 74.33 & 39.77 \\
\hline Firm size: big & 1 if the average number of workers in the firm in 2010 could be found and was 50 or more, 0 otherwise & 0.215 & - \\
\hline Firm size: small & 1 if the average number of workers in the firm in 2010 could be found and was less than 50,0 otherwise & 0.381 & - \\
\hline Firm size: unknown & 1 if the average number of workers in the firm in 2010 could not be found, 0 otherwise & 0.404 & - \\
\hline Technology intensity in sector: high & $\begin{array}{l}1 \text { if the sector was labelled as 'High Technology / Knowledge Intensive Services' following Mahy, Rycx and Vermeylen } \\
\text { (2015), } 0 \text { otherwise }\end{array}$ & 0.505 & - \\
\hline Technology intensity in sector: low & $\begin{array}{l}1 \text { if the sector was not labelled as 'High Technology / Knowledge Intensive Services' following Mahy et al. (2015), } \\
0 \text { otherwise }\end{array}$ & 0.194 & - \\
\hline $\begin{array}{l}\text { Technology intensity in sector: } \\
\text { unknown }\end{array}$ & 1 if the sector could not be labelled with respect to technology intensity following Mahy et al. (2015), 0 otherwise & 0.301 & - \\
\hline \multicolumn{4}{|l|}{ D. Outcome } \\
\hline Interview invitation & 1 if the candidate receives an interview invitation, 0 otherwise & 0.216 & - \\
\hline
\end{tabular}

Notes. No standard deviations are reported for binary variables. The number of observations (job applications) is 1248 . See Section 2 for a description of the data gathering process.

\subsection{Variation in vacancy and employer characteristics}

Apart from looking at whether the treatment effect is heterogeneous with respect to the aforementioned application characteristics that were randomised across vacancies (gender, resume length, and additionally mentioned skills), we also investigate whether the responses by the prospective employer depend on the required field of study, the labour market tightness of the occupation, and employer characteristics.

First, we differentiate between vacancies for graduates with a humanities and social sciences degree and those for graduates with an exact science degree. Earlier research by Margaryan et al. (2020) found the effect of internships during studies on wages to be more pronounced for graduates with humanities and social sciences degrees. This is consistent with the often-reported oversupply of graduates with humanities and social sciences degrees, making internships an important factor to distinguish oneself on the labour market. Another explanation for a more favourable effect of internships in the case of humanities and social sciences may be that students within humanities and social sciences acquire relatively less specific knowledge and competencies during their educational career in comparison to students in exact sciences, making internships relatively more valuable for them.

Second, to investigate more directly whether demand and supply conditions might matter, we differentiate between vacancies for occupations with high and low labour market tightness. This tightness is proxied by the median vacancy duration in days for all vacancies in the occupation in the database of the Public Employment Agency of Flanders in 2015 (Baert et al., 2015; VDAB, 2015). When a vacancy is difficult to fill, employers are faced with a smaller pool of applicants from which they can select a candidate. The room for (un)favourable treatment of applicants with or without a certain characteristic, in our case the voluntary firm internship during studies, is smaller in that case (Baert et al., 2015). We thus expect the internship treatment effect to be negatively related to the median vacancy duration of the occupation.

Third, we look at whether the treatment effect is heterogeneous by firm size. The information on firm size, defined as the average number of workers in the firm in 2010, was retrieved from the Bel-First database.
We differentiate between relatively small firms (less than 50 workers on average in 2010) and relatively large firms (more than 50 workers on average in 2010). A third category with 'unknown firm size' includes the firms for which the average number of workers was not included in Belfirst. Firm size may affect the strength of the treatment effect in both directions. On the one hand, large firms may face higher monitoring costs and may thus be more inclined to rely on external signals such as internship experience (Stigler, 1962). On the other hand, large firms may just as well be less selective as the risk of hiring a bad match is likely to be distributed across several hiring decisions. This risk spreading is not possible in small firms, making these companies probably more likely to discriminate against students without an internship.

Last, we investigate whether the treatment effect is heterogeneous with respect to the technological intensity of the sector in which the firm operates. The technological intensity is labelled high or low following the 'High Technology (HT) Industry / Knowledge Intensive Services (KIS)' nomenclature developed by Eurostat (2016). ${ }^{17}$ A third group with 'unknown technological intensity' includes the firms for which we were not able to identify the technological intensity and the employment agencies, as these agencies most likely are not recruiting for their firm. Firms confronted with fast technological change are expected to be less eager to hire students with an internship, as a significant part of the knowledge and competencies acquired during an internship is likely to be rather specific and therefore vulnerable to becoming obsolete quickly (Gault et al., 2000).

\subsection{Data description}

Table 2 provides an overview of all variables within our dataset and reports their means ${ }^{18}$ and standard deviations. We consider four groups of variables, namely (i) the treatment, (ii) the other applicant characteristics, (iii) the vacancy characteristics, and (iv) the outcome measure.

\footnotetext{
17 This framework is adopted from Mahy, Rycx, and Vermeylen (2015).

18 When the means are broken down by treatment status, they are, by construction, exactly the same for the two subsamples.
} 
Table 3

Bivariate analysis.

\begin{tabular}{|c|c|c|c|c|c|c|c|}
\hline \multirow[t]{2}{*}{$\begin{array}{l}\text { Subsample by candidate } \\
\text { characteristics }\end{array}$} & \multirow[t]{2}{*}{$\begin{array}{l}\text { (1) } \\
\text { Number of } \\
\text { vacancies }\end{array}$} & $\begin{array}{l}\text { (2) } \\
\text { Invitation rate }\end{array}$ & (3) & \multirow[t]{2}{*}{$\begin{array}{l}\text { (4) } \\
\text { Difference in invitation rate: } \\
(2)-(3)\end{array}$} & \multirow[t]{2}{*}{$\begin{array}{l}\text { (5) } \\
\text { Invitation ratio: (2) / } \\
(3)\end{array}$} & \multicolumn{2}{|c|}{$\begin{array}{l}\text { Significance of (4) } \\
\text { and (5): }\end{array}$} \\
\hline & & $\begin{array}{l}\text { Candidate with } \\
\text { internship }\end{array}$ & $\begin{array}{l}\text { Control } \\
\text { candidate }\end{array}$ & & & $\begin{array}{l}\mathrm{P} \text { - } \\
\text { value }\end{array}$ & $\begin{array}{l}\mathrm{T}- \\
\text { value }\end{array}$ \\
\hline Full sample & 624 & 0.229 & 0.204 & 0.025 & 1.126 & 0.016 & 2.422 \\
\hline Female & 312 & 0.205 & 0.179 & 0.026 & 1.143 & 0.045 & 2.010 \\
\hline Male & 312 & 0.253 & 0.228 & 0.025 & 1.113 & 0.131 & 1.515 \\
\hline Extended resume & 312 & 0.250 & 0.234 & 0.016 & 1.068 & 0.276 & 1.091 \\
\hline Limited resume & 312 & 0.208 & 0.173 & 0.035 & 1.204 & 0.022 & 2.310 \\
\hline Additional skills: hard & 208 & 0.226 & 0.192 & 0.034 & 1.175 & 0.109 & 1.612 \\
\hline Additional skills: soft & 208 & 0.236 & 0.221 & 0.015 & 1.065 & 0.440 & 0.774 \\
\hline Additional skills: none & 208 & 0.226 & 0.197 & 0.029 & 1.146 & 0.058 & 1.909 \\
\hline Humanities and social sciences & 240 & 0.200 & 0.158 & 0.042 & 1.263 & 0.007 & 2.708 \\
\hline Exact sciences & 384 & 0.247 & 0.232 & 0.015 & 1.067 & 0.274 & 1.096 \\
\hline
\end{tabular}

Notes. The p-values (column 6) are based on a $t$-test testing the null hypothesis that the invitation ratio is not significantly different from 1 (testing whether the difference in invitation rate is not different from 0 yields the same values).

Apart from the field of study, all applicant characteristics ((i) and (ii)) were under control in our experiment by means of randomisation. This randomisation is reflected in the statistics in Panels A and B. With respect to the outcome variable, we find that more than one in five applicants (21.6\%) received an interview invitation.

\subsection{Limitations of the experimental design}

We end this section with a discussion of the limitations of our experimental design. For an in-depth discussion of the ethical aspects of the correspondence experimentation framework, we refer to Riach \& Rich, 2004. An important limitation of this study is the generalisability.

First, we only focus on a specific_but crucial-labour market outcome, namely the initial hiring decisions of employers (outside the candidates' network) for the first job of graduates. Therefore, our research cannot inform about potential differences in final hiring decisions, let alone in wages and long-term labour market outcomes after graduation. Note that this is a general weakness of correspondence experiments aiming at examining causal effects on labour market success in terms of job interview invitations (e.g. Baert et al., 2015; Bertrand \& Mullainathan, 2004; Eriksson \& Rooth, 2014; Kroft et al., 2013; Nunley et al., 2016). Nonetheless, previous research indicates that the invitation to the first job interview is a critical factor for the chances to be hired (Cédiey, Foroni, \& Garner, 2008). Furthermore, if we observe a preference for certain applicants, the absence of information beyond the callback would only be worrisome if, conditional on the callback, the probability of hiring alters with internship experience. Employers might have different assumptions (true or not) about the variance in productivity among those with in comparison to those without an internship, leading to differences in callback between these two groups even in the absence of a difference in mean productivity (Heckman \& Siegelman, 1993; Neumark, 2012). ${ }^{19}$ To address this concern, we examine employer invitations for a job interview rather than a general callback, as the former delivers a stronger indication of employers' preferences (Deming et al., 2016). The only method to truly overcome this limitation and obtain causal measures of the treatment effect of student internship on later labour market success of the recruitment process is audit testing in which actors partake in job interviews. However, audit tests are costly and have been criticised on various grounds (Heckman \& Siegelman, 1993; Riach \& Rich, 2002).

Second, due to methodological reasons, we solely investigate the impact of voluntary intra-curricular internships. Our results can

\footnotetext{
19 This means that, if a limited number of interview slots is open for applicants, employers may invite more applicants from groups with a high variance in productivity.
}

therefore not be translated to the impact of mandatory internships. Third, even though we selected various study programmes within different study fields, full representation for all fields of study cannot be achieved. We only focus on applicants with a master's degree within the selected master's programmes and only apply for particular vacancies posted at the Flemish Public Employment Agency. This problem is inherent to the experimental framework and is traded off against the benefit of resolving the endogeneity of educational choices and unobservable factors with respect to labour market success.

\section{Results}

\subsection{Bivariate analyses}

In this section, we describe the bivariate results. Table 3 reports the number of tested vacancies and the invitation rates for the full sample and various subsamples. For all (sub)samples, the average probability of obtaining an invitation to a job interview is displayed for both the treatment group (graduates with an internship) and the control group (graduates without an internship) (column 2 and 3 of Table 3).

Overall, we find that students with internship experience get an invitation to a job interview in $22.9 \%$ of their applications, in contrast to $20.4 \%$ for the control group. So, an internship experience increases the invitation probability by 2.5 percentage points (column 4 of Table 3 ). The ratio of the invitation rates (column 5 of Table 3) is 1.126, suggesting that applicants with a firm internship experience during university get as much as $12.6 \%$ more invitations. This ratio is different from one at the $5 \%$ significance level. This suggests that employers treat students with internship experience more favourably than students without this labour market experience. So, the statistics for the overall sample indicate that student internships boost early career success.

Next, we look at subsamples by the other applicant characteristics. Splitting the overall sample by gender, we find that only the subsample of women has a significantly higher interview rate when they mention an internship experience. The response ratio for women is equal to 1.143 and is statistically different from one at the $5 \%$ level, indicating that women with an internship get $14.3 \%$ more interview requests than the female control group.

Dividing the overall sample by resume length (extensive versus limited resume), we find that only the limited resume subsample generates a significantly positive internship effect. Applicants with a limited resume and an internship experience are found to have $20.4 \%$ more interview requests than their otherwise identical peers without this experience. Next, we investigate whether the recruiters' behaviour depends on the additional skills (additional credits or courses) mentioned in the resume. We only find a significant effect of internship experience for those mentioning no additional credits or courses. 
Table 4

Multivariate analysis.

\begin{tabular}{|c|c|c|c|}
\hline & (1) & (2) & (3) \\
\hline Internship & $\begin{array}{l}1.163^{* *} \\
(0.073)\end{array}$ & $\begin{array}{l}1.188^{* * *} \\
(0.076)\end{array}$ & $\begin{array}{l}1.201 * * \\
(0.085)\end{array}$ \\
\hline Internship x Female (demeaned) & & $\begin{array}{l}1.028 \\
(0.128)\end{array}$ & $\begin{array}{l}1.030 \\
(0.131)\end{array}$ \\
\hline $\begin{array}{l}\text { Internship x Extended resume } \\
\text { (demeaned) }\end{array}$ & & $\begin{array}{l}0.865 \\
(0.111)\end{array}$ & $\begin{array}{l}0.861 \\
(0.112)\end{array}$ \\
\hline $\begin{array}{l}\text { Internship x Additional skills: hard } \\
\text { (demeaned) }\end{array}$ & & $\begin{array}{l}1.032 \\
(0.162)\end{array}$ & $\begin{array}{l}1.025 \\
(0.172)\end{array}$ \\
\hline $\begin{array}{l}\text { Internship x Additional skills: soft } \\
\text { (demeaned) }\end{array}$ & & $\begin{array}{l}0.911 \\
(0.128)\end{array}$ & $\begin{array}{l}0.913 \\
(0.139)\end{array}$ \\
\hline \multicolumn{4}{|c|}{ Internship $x$ Additional skills: none (reference) } \\
\hline $\begin{array}{l}\text { Internship x Humanities and social } \\
\text { sciences (demeaned) }\end{array}$ & & $\begin{array}{l}1.224 \\
(0.161)\end{array}$ & $\begin{array}{l}1.194 \\
(0.168)\end{array}$ \\
\hline $\begin{array}{l}\text { Internship x Median vacancy } \\
\text { duration (demeaned) }\end{array}$ & & & $\begin{array}{l}1.000 \\
(0.001)\end{array}$ \\
\hline $\begin{array}{l}\text { Internship x Firm size: big } \\
\text { (demeaned) }\end{array}$ & & & $\begin{array}{l}1.139 \\
(0.215)\end{array}$ \\
\hline $\begin{array}{l}\text { Internship x Firm size: unknown } \\
\text { (demeaned) }\end{array}$ & & & $\begin{array}{l}1.076 \\
(0.155)\end{array}$ \\
\hline \multicolumn{4}{|l|}{ Internship x Firm size: small (reference) } \\
\hline $\begin{array}{l}\text { Internship x Technology intensity in } \\
\text { sector: high (demeaned) }\end{array}$ & & & $\begin{array}{l}0.824 \\
(0.157)\end{array}$ \\
\hline $\begin{array}{l}\text { Internship x Technology intensity in } \\
\text { sector: unknown (demeaned) }\end{array}$ & & & $\begin{array}{l}0.775 \\
(0.187)\end{array}$ \\
\hline \multicolumn{4}{|c|}{ Internship $x$ Technology intensity in sector: low (reference) } \\
\hline Female (demeaned) & & $\begin{array}{l}0.739 \\
(0.149)\end{array}$ & $\begin{array}{l}0.713^{*} \\
(0.146)\end{array}$ \\
\hline Extended resume (demeaned) & & $\begin{array}{l}1.466^{*} \\
(0.296)\end{array}$ & $\begin{array}{l}1.476 * \\
(0.302)\end{array}$ \\
\hline Additional skills: hard (demeaned) & & $\begin{array}{l}0.969 \\
(0.244)\end{array}$ & $\begin{array}{l}0.966 \\
(0.249)\end{array}$ \\
\hline Additional skills: soft (demeaned) & & $\begin{array}{l}1.160 \\
(0.283)\end{array}$ & $\begin{array}{l}1.043 \\
(0.262)\end{array}$ \\
\hline \multicolumn{4}{|l|}{ Additional skills: none (reference) } \\
\hline $\begin{array}{l}\text { Humanities and social sciences } \\
\text { (demeaned) }\end{array}$ & & $\begin{array}{l}0.621 * * \\
(0.133)\end{array}$ & $\begin{array}{l}0.689 * * \\
(0.159)\end{array}$ \\
\hline $\begin{array}{l}\text { Median vacancy duration } \\
\text { (demeaned) }\end{array}$ & & & $\begin{array}{l}1.004 \\
(0.003)\end{array}$ \\
\hline Firm size: big (demeaned) & & & $\begin{array}{l}0.619 \\
(0.183)\end{array}$ \\
\hline Firm size: unknown (demeaned) & & & $\begin{array}{l}0.847 \\
(0.194)\end{array}$ \\
\hline \multicolumn{4}{|l|}{ Firm size: small (reference) } \\
\hline $\begin{array}{l}\text { Technology intensity in sector: high } \\
\text { (demeaned) }\end{array}$ & & & $\begin{array}{l}1.991 * * \\
(0.589)\end{array}$ \\
\hline $\begin{array}{l}\text { Technology intensity in sector: } \\
\text { unknown (demeaned) }\end{array}$ & & & $\begin{array}{l}0.963 \\
(0.337)\end{array}$ \\
\hline \multicolumn{4}{|c|}{ Technology intensity in sector: low (reference) } \\
\hline Observations & 1248 & 1248 & 1248 \\
\hline
\end{tabular}

Notes. The presented statistics are odds ratios based on a logistic regression. The dependant variable is 1 when the candidate receives a job interview, and 0 otherwise. Standard errors, corrected for clustering at the vacancy level, are in parentheses. $\left.{ }^{* * *}\right)((* * *))$ indicates significance at the $10 \%(5 \%)((1 \%))$ level.

Finally, we break down the data by the field of study. We find that the overall positive effect of internships on the invitation rate is driven by applicants from the field of humanities and social sciences. For them, the invitation ratio is statistically different from one at the $1 \%$ significance level. Graduates within the field of humanities and social sciences with an internship experience receive $26.3 \%$ more interview requests than their otherwise identical peers without internship experience. This confirms earlier findings in this respect by Margaryan et al. (2020).

\subsection{Multivariate analyses}

The invitation ratios reported in the previous section allow us to assess whether the main conclusion is robust across various subsamples, but they do not reveal whether differences in relative responses across various subgroups of candidates are statistically significant. Furthermore, the bivariate analyses are less suited to investigate the role of the considered vacancy and employer characteristics since these characteristics may be correlated with each other and, by the finite nature of our data, with the candidate characteristics. Therefore, we estimate multivariate logistic regressions with the individual application as the observation unit and receiving an invitation to a job interview as the outcome variable. The dichotomous outcome measure is equal to one for applicants with an invitation to a job interview, and zero in case of another reaction or no response. The results are reported in Table 4.

First, we estimate a logistic model (Model 1) including only the internship dummy variable. The results of this analysis confirm our findings of the bivariate analysis. As the odds ratio of 1.163 is significantly larger than one, we conclude that an internship experience indeed positively impacts the likelihood of an invitation to a job interview.

Second, we examine the heterogeneity of the internship effect concerning the applicant characteristics. To this end, we include dummy variables for the variables capturing the gender, resume length, additional skills, and field of study of the candidate, as well as interactions between these characteristics and the internship dummy variable (Model 2). While the bivariate analysis indicated that the results with respect to the likelihood of receiving an invitation to a job interview were mainly driven by the subsample of women, we no longer find significant gender differences in the multivariate analysis. Similarly, while the bivariate analyses suggested the treatment effect depends on the resume length (extensive versus limited), the additional hard or soft skills and the field of study, we do not obtain any significant interaction effects between these variables and the internship dummy variable. Our aforementioned conclusion concerning the role of internships as signals for work motivation and producers of hard and soft skills can therefore not be retained. ${ }^{20}$

In the third specification, we investigate whether the employers' recruitment behaviour regarding internship experience depends on vacancy and employer characteristics such as the labour market tightness in the occupation, firm size, and technology intensity of the sector. None of the additionally added interaction effects are statistically significant, suggesting that the internship effect does not differ with respect to any of these characteristics.

Finally, we perform various robustness analyses. ${ }^{21}$ An analysis with vacancy, occupation and/or sector fixed effects, as well as an analysis with other indicators of labour market tightness, and an analysis in which an interaction with an indicator for KU Leuven (versus Ghent University as a reference) are added, yield similar conclusions. Furthermore, we perform various regression models such as a linear probability model and an ordered logistic regression model (with ' 2 ' an immediate interview invitation, ' 1 ' any other positive reaction and ' 0 ' a negative or no reaction). Also these models yield similar results. Last, we include three-way interactions. These interactions are found to be insignificant and the main conclusions remain.

\subsection{Discussion}

Overall, we find that graduates with internship experience receive $12.6 \%$ more invitations to job interviews. To shed some light on the size of the effect, we compare our findings with those from the aforementioned correspondence experiments. First, our internship effect is quite comparable with the aforementioned $14.3 \%$ more invitations for graduates with extra-curricular internship experience in the United States reported by Nunley et al. (2016). Second, among others, Bertrand and Mullainathan (2004) report differences in invitation rates for job interviews between low- and high-quality resumes in the United States. High-quality candidates are defined as the following: 'Higher-quality

\footnotetext{
${ }^{20}$ When running the regression analysis with one general dummy variable for additional skills, instead of the two dummy variables for hard and soft skills, no significant interaction effect is found for these skills.

${ }^{21}$ The detailed estimation results are available upon request.
} 
applicants have on average a little more labour market experience and fewer holes in their employment history; they are also more likely to have an email address, have completed some certification degree, possess foreign language skills, or have been awarded some honors (Bertrand \& Mullainathan, 2004, p. 992).' From this description, one might expect that the strength of the treatment (capturing a bundle of different treatments) in their case might be larger in magnitude compared to the difference in invitation rates for graduates with and without an internship experience. Indeed, Bertrand and Mullainathan (2004) find a statistically significant difference of $26.9 \%$ between highand low-quality resumes, compared to a difference of $12.6 \%$ in our study. Third, the invitation ratio of 1.126 found in the present study is also lower than the invitation ratios of 1.170 and 1.409 found by Baert and Verhaest (2019) comparing recent graduates with individuals who graduated a year earlier and had been underemployed or unemployed since that time.

With respect to the lack of evidence on the heterogeneity of the internship effect by other candidate characteristics as well as by the labour market tightness in the occupation and firm characteristics, one could argue that our null interaction effects rather reflect the finite size of our sample than a genuine null effect. However, it is important to keep in mind that, both in our bivariate and in our multivariate analysis, we investigate dimensions of heterogeneity in the internship premium dimension by dimension. As a consequence of this, and of the balanced nature of our experimental data by characteristics such as education level and gender, the number of observations in most of the relevant cells is 624 or 416 , i.e. 2 (candidates) times 312 (half of the vacancies tested) or 208 (a third of the vacancies tested). Even the smallest subsample in our data, i.e. that with vacancies with a low technology intensity in the sector, comprises 121 vacancies and 242 applications. Moreover, the internship premiums presented in Table 3 lie within a rather small interval, with a 1.5 percentage points (applications with extra soft skills and applications with exact sciences as the field of study) and a 4.2 percentage points (applications with humanities and social sciences as the field of study) increase in invitation rates as boundaries. Finally, additional power calculations, taking the comparable experiment of Nunley et al. (2016) as reference for the assessment of the 'true' effect, indicate power levels for the estimated interaction effects to range from $26.1 \%$ to $39.8 \%$ for a $10 \%$ significance threshold (see Appendix A1). Although the risk on Type II errors is considerable in this case, one would nonetheless expect at least some of the interactions to be statistically significant. ${ }^{22}$ Therefore, we believe the true level of heterogeneity in the internship premium to be at best rather small.

\section{Conclusion}

This study contributed to the small empirical literature on the effect of internship experience on labour market success. We argued that many earlier studies examining this effect had been unable to estimate a causal relationship because of endogeneity problems. We contributed to this literature by estimating the causal impact of voluntary intra-curricular internship experience during university studies on the probability of being invited to a job interview by means of a correspondence experiment. We found that university graduates with internship experience are more likely to be invited to a job interview compared to students without this experience. Moroever, we did not find evidence for this effect to be heterogeneous by other candidate characteristics such as gender and field of study as well as by the labour market tightness in the occupation, firm size and technology intensity of the sector.

Several important implications can be drawn from these results. First of all, they confirm that the positive relationship between internship

\footnotetext{
${ }^{22}$ Note also that the power levels for the interaction effects are close or above the median power achieved in empirical economics studies, as reported by Ioannidis et al. (2017).
}

experience and labour market success is more than just a correlational one. This is in line with Nunley et al. (2016), who relied on a similar design, as well as with Margaryan et al. (2020), who relied on instrumental variable estimation strategy. Nonetheless, several other quasi-experimental studies did not identify any positive effect. One explanation for these different findings may be our focus on the chances to be invited to a job interview. If applicants with an intership have a higher variance in productivity, this may translate in higher job interview chances only. However, since Margaryan et al. (2020) did find a positive impact on earnings as well, this cannot be the full story. Second, some of the quasi-experimental studies that did not detect a positive association applied matching related techniques. These approaches rely on strong identifying assumptions which may not always be met. Third, the internship effect may depend on the type of internship that is considered. This is in line with Weiss et al. (2014) and also consistent with the lack of evidence on mandatory internships in Klein and Weiss (2011) and Verhaest and Baert (2018). As argued, the signalling effect may be lower in the case of mandatory intra-curricular work experiences, the effect which the latter authors study.

A second implication is related to the mechanism explaining the relationship between internships and labour market outcomes. Since our experiment only considers jobs outside the network of the fictitious graduates, the estimated internship effect cannot be due to networking or on-the-job screening effects and may thus represent a lower bound. With respect to the question whether the estimated effect is primarily explained by human capital or signalling theory, our results were less conclusive. The relative importance of these two mechanisms was tested by including variations of additional resume characteristics such as length and additional skills. While our bivariate results suggested that both mechanisms matter, our regression analysis did not detect significant differences in treatment effects depending on these resume characteristics. Employers probably consider the signalling and human capital value of these additional resume characteristics to be relatively low, thus making it difficult to distinguish between the signalling and human capital value of internships by adding variations of these characteristics to the resume. Another explanation may be that employers consider internships and the other resume attributes to be signals of different rather than the same characteristics. If so, there is no reason to expect the effect of internship experience to depend on the length of the resume.

Overall, our findings confirm that offering students the option to undertake an internship is an effective strategy for universities to enhance the labour market outcomes of their graduates, even if these internships substitute for another elective course. Nonetheless, to guide universities and graduates, we advise several further avenues for research. First of all, as we looked at one particular type of intersnhips only, research looking more directly at the differential impact of alternative types of internships (extra- versus intra-curricular, voluntary versus mandatory) is necessary. Second, more research is needed to study the extent to which the effectiveness of internships depends on their content, the orientation of a person's study programme, and the relationship between both. Finally, additional research is needed to assess the relative importance of the signalling and human capital channel of internships, for instance, by relying on stated choice experiments.

\section{Ethical approval}

The present research was approved by the Ethical Committee of the Faculty of Economics and Business Administration of Ghent University.

\section{CRediT authorship contribution statement}

By Stijn Baert: Conceptualization, Methodology, Formal analysis, Investigation, Data curtion, Writing - review \& editing, Supervision, Project administration. Brecht Neyt: Investigation, Writing - original 
draft, Writing - review \& editing. Thomas Siedler: Conceptualization, Methodology, Writing - review \& editing. Ilse Tobback: Formal analysis, Investigation, Data curtion, Writing - original draft, Writing - review \& editing. Dieter Verhaest: Conceptualization, Methodology, Formal analysis, Investigation, Writing - original draft, Writing - review \& editing, Supervision.

\section{Declaration of Competing Interest}

The authors declare that they have no relevant or material financial interests that relate to the research described in this paper.

\section{Acknowledgements}

We thank Yana Bosmans, Ella Dewaele, Mart Dierken, and Sarah Tanghe for their excellent research assistance. In addition, we are grateful to the Public Employment Agency of Flanders (VDAB) for the provided statistics.

\section{Appendix A1. Statistical power}

To assess statistical power, one needs information on the 'true effect' of an internship on the job invitation rate. Since this information is lacking, post-hoc power calculations are often based on the point estimate of the study itself. However, such calculations are circular as they merely reflect the reported $\mathrm{p}$ values. A more appropriate way to gauge the true effect is to rely on earlier evidence in the literature (Ioannidis et al., 2017). As Nunley et al. (2016) is the only other study to date having investigated the impact of internship experience on job invitation rates by means of a correspondence experiment, we rely on their reported effect of $14.3 \%$ (or $2.91 \%$-points) ${ }^{23}$ more invitations for those with internship experience to assess the power of our study. For a 5\% (10\%) significance, the power level is then calculated by the probability in the cumulative normal distribution for $z=(\alpha /$ s.e. -1.96$)(z=(\alpha / \mathrm{s}$. e. -1.64$)$ ), with $\alpha$ being the 'true' effect in \%-points as gauged based on Nunley et al. (2016) and s.e. being the standard error of our own estimate.

We first calculate the realised power for the effect of internships on the number of job invitations in our full sample (see Table 3 (first row) and Table 4 (Model (1)), which is our main parameter of interest. As reported in Table A1, in combination with a $5 \%(10 \%)$ significance level, the power level of our main analysis would be $78.4 \%(86.4 \%)$ in case the 'true' job interview ratio of an internship over no internship were equal to the one found in the study of Nunley et al. (2016). ${ }^{24}$ Not only is this estimate close to (above) the conventional $80 \%$ power level, it also well exceeds the median power realised in empirical economics studies; Ioannidis et al. (2017) found that between 53\% and $64 \%$ of all economics research fields achieve a median power level of less than $20 \%$ when combined with a $5 \%$ statistical significance level.

In Table A1, we also report achieved power for two of the estimated interaction effects in our study (Table 4, model (3)): the interaction effect between internship and extended resume, and the interaction effect between internship and big firm (Table 4, model (4)). These two

\footnotetext{
${ }^{23}$ To make the estimated \%-point effect equivalent to the baseline job invitation rate in our study, it is derived from the estimated invitation rate of 0.204 for the control group in our study (see Table 3, Column (3); $0.204 * 0.143 \approx 0.0291$ ).

${ }^{24}$ The standard error on the estimated \%-point effect, needed to estimate these power levels, is derived from a linear probability model (with robust and clustered standard errors) that regresses the job invitation dummy on the internship dummy.
}

Table A1

Achieved power for a selection of estimates and based on a hypothetical true effect as estimated by ${ }^{\text {Nunley et al. (2016)a }}$.

\begin{tabular}{llll}
\hline & $\begin{array}{l}\text { (1) } \\
\text { Main } \\
\text { effect }\end{array}$ & $\begin{array}{l}\text { (2) } \\
\text { Interaction effect } \\
\text { Internship x Extended } \\
\text { resume }\end{array}$ & $\begin{array}{l}\text { (3) } \\
\text { Interaction effect } \\
\text { Internship x Firm size: } \\
\text { big }\end{array}$ \\
\hline $\begin{array}{l}\text { Significance } \\
\text { level of 5\% }\end{array}$ & $78.4 \%$ & $28.3 \%$ & $17.0 \%$ \\
$\begin{array}{c}\text { Significance } \\
\text { level of 10\% }\end{array}$ & $86.4 \%$ & $39.8 \%$ & $26.1 \%$ \\
\hline $\begin{array}{l}\text { Notes:. } \\
\text { a Nunley et al. (2016) reported internships experience to increase the number }\end{array}$ \\
$\begin{array}{l}\text { of job interview invitations by 14,3\%; the standard errors, required to calculate } \\
\text { the power levels, are derived from linear probability models (with robust and } \\
\text { clustered standard errors) similar to the logistic model as reported in Table 4 } \\
\text { (Model (1) for the main effect and Model (3) for the interaction effects). }\end{array}$
\end{tabular}

interactions are chosen since they are associated with the lowest and highest estimated standard error respectively. ${ }^{25}$ Evaluated at a hypothetical true effect that is equal to the estimated main effect by Nunley et al. (2016) (14.3\% (or 2.91\%-points)) more invitations), calculated power levels range from $17.0 \%(26.1 \%)$ to $28.3 \%(39.8 \%)$ in combination with a significance level of $5 \%(10 \%) .{ }^{26}$ While being well below the conventional $80 \%$, also these power levels are still at least as high as those realised in most empirical economics studies (cf. supra).

\section{References}

Baert, S. (2018), Hiring discrimination: An overview of (almost) all correspondence experiments since 2005. In M. Gaddis (Ed.), Audit studies: Behind the scenes with theory, method, and nuance (pp. 63-80). New York, NY: Springer.

Baert, S., Cockx, B., Gheyle, N., \& Vandamme, C. (2015). Is there less discrimination in occupations where recruitment is difficult? ILR Review, 68, 467-500.

Baert, S., Rotsaert, O., Verhaest, D., \& Omey, E. (2016). Student employment and later labour market success: No evidence for higher employment chances. Kyklos, 69, $401-425$.

Baert, S., \& Verhaest, D. (2019). Unemployment or Overeducation: Which is a Worse Signal to Employers? De Economist, 167, 1-21.

Baert, S., \& Vujić, S. (2018). Does it pay to care? Volunteering and employment opportunities. Journal of Population Economics, 31, 819-836.

Becker, G. S. (1964). Human capital: A theoretical and empirical analysis, with special reference to education. New York: National Bureau of Economic Research.

Bertrand, M., \& Mullainathan, S. (2004). Are Emily and Greg more employable than Lakisha and Jamal? A field experiment on labour market discrimination. American Economic Review, 94, 991-1013.

Callanan, G., \& Benzing, C. (2004). Assessing the role of internships in the careeroriented employment of graduating college students. Education + Training, 46, 82-89.

Cédiey, E., Foroni, F., \& Garner, H. (2008). Discriminations à l'Embauche Fondées sur l'Origine à l'Encontre de Jeunes Français(es) peu Qualifié(e)s. Une Enquête Nationale par Tests de Discrimination ou Testing. DARES, Premières Synthèses Information, 6.

Cerulli-Harms, A. (2017). Generation internship: The impact of internships on early labour market performance, Bonn. Institute for the Study of Labor. IZA discussion papers no.11163.

Chen, C.-T., Hu, J.-L., Wang, C.-C., \& Chen, C-Fu (2011). A study of the effects of internship experiences on the behavioural intentions of college students majoring in leisure management in Taiwan. Journal of Hospitality Leisure Sport \& Tourism Education, 10, 61-73.

Cook, S., Parker, S., \& Pettijohn, C. E. (2004). The perceptions of interns: A longitudinal case study. Journal of Education for Business, 79, 179-185.

Deming, D., Yuchtman, N., Abulafi, A., Goldin, C., \& Katz, L. (2016). The value of postsecondary credentials in the labour market: An experimental study. American Economic Review, 106, 778-806.

\footnotetext{
${ }^{25}$ We abstract from the interaction effect regarding the median vacancy duration (as this is a continuous measure) and the interaction effects with the "unknown" categories.

26 The standard errors on the estimated \%-point interaction effects, needed to estimate these power levels, are derived from a linear probability model (with robust and clustered standard errors) similar to the logistic model as reported in Table 4, Model (3).
} 
Divine, R. L., Linrud, JK., Miller, RH., \& Holton Wilson, J. (2007). Required internship programs in marketing: Benefits, challenges and determinants of fit. Marketing Education Review, 17, 45-52.

Drydakis, N. (2016). The effect of university attended on graduates' labour market prospects: A field study of Great Britain. Economics of Education Review, 52, 192-208.

Eriksson, S., \& Rooth, D.-O. (2014). Do employers use unemployment as a sorting criterion when hiring? Evidence from a FIELD Experiment. American Economic Review, 104, 1014-1039.

Eurostat (2016). High-tech industry and knowledge-intensive services (HTEC). Retrieved from http://ec.europa.eu/eurostat/cache/metadata/en/htec_esms.htm.

European Commission. (2013). The experience of traineeships in the EU. Flash Eurobarometer, 378.

Gault, J., Leach, E., \& Duey, M. (2010). Effects of business internships on job marketability: The employers' perspective. Education + Training, 52, 76-88.

Gault, J., Redington, J., \& Schlager, T. (2000). Undergraduate business internships and career success: Are they related? Journal of Marketing Education, 22, 45-53.

Granovetter, M. S. (1973). The strength of weak ties. American Journal of Sociology, 78, $1360-1380$

Heckman, JJ., \& Siegelman, P. (1993). The urban institute audit studies: Their methods and findings. In M. Fix, \& R. Struyk (Eds.), Clear and convincing evidence: Measurement of discrimination in America. Washington DC: Urban Institute Press.

Holford, A. (2017). Access to and returns from unpaid graduate internships. ISER working paper series, 2017-07. Essex: Institute for Social and Economic Research.

Ioannidis, JP. A., Stanley, T. D., \& Doucouliagos, H. (2017). The power of bias in economics research. The Economic Journal, 127, F236-F265.

Jovanovic, B. (1979). Job matching and the theory of turnover. Journal of Political Economy, 87, 972-990.

Klein, M., \& Weiss, F. (2011). Is forcing them worth the effort? Benefits of mandatory internships for graduates from diverse family backgrounds at labour market entry. Studies in Higher Education, 36, 969-987.

Knouse, SB., Tanner, JR., \& Harris, EW. (1999). The relation of college internships, college performance, and subsequent job opportunity. Journal of Employment Counseling, 36, 35-43.

Krawietz, M., Müßig-Trapp, P., \& Willige, J. (2006). HISBUS Blitzbefragung: Praktika im Studium. HISBUS Kurzinformation Kurzbericht, 13.

Kroft, K., Lange, F., \& Notowidigdo, MJ. (2013). Duration dependence and labour market conditions: Evidence from a field experiment. Quarterly Journal of Economics, 128, 1123-1167.

Lahey, J., \& Beasley, R. (2016). Technical aspects of correspondence studies. NBER working paper series no. 22818. New York: National Bureau of Economic Research.

Mahy, B., Rycx, F., \& Vermeylen, G. (2015). Educational mismatch and firm productivity: do skills, technology and uncertainty matter? De Economist, 163, 233-262.

Margaryan, S., Saniter, N., Schumann, M., \& Siedler, T. (2020). Do internships pay off? The effects of student internships on earnings. Journal of Human Resources. https:// doi.org/10.3368/jhr.57.4.0418-9460R2. Published online before print.

Mihail, DM. (2006). Internships at Greek universities: An exploratory study. Journal of Workplace Learning, 18, 28-41.

Morrow, E. P. (1995). An intern can help you. Life and Insurance Sales, 138, 60-70.

Neumark, D. (2012). Detecting discrimination in audit and correspondence studies. Journal of Human Resources, 47, 1128-1157.
Neumark, D. (2018). Experimental research on labour market discrimination. Journal of Economic Literature, 56, 799-866.

Neumark, D., \& Rothstein, D. (2007). Do School-to-work programs help the "forgotten half'? In D Neumark (Ed.), Improving school-to-work transitions (pp. 87-133). New York: Russell Sage Foundation.

Nunley, JM., Pugh, A., Romero, N., \& Seals, R. A (2016). College major, internship experience, and employment opportunities: Estimates from a Résumé audit. Labour Economics, 38, 37-46.

Pager, D. (2007). The use of field experiments for studies of employment discrimination: contributions, critiques, and directions for the future. The Annals of the American Academy of Political and Social Science, 609, 104-133.

Pasewark, W. R., Strawser, J. R., \& Wilkerson, J. E. (1989). An empirical examination of the effect of previous internship experience on interviewing success. Journal of Accounting Education, 7, 25-39.

Riach, P. A., \& Rich, J. (2002). Field experiments of discrimination in the market place. Economic Journal, 112, F480-F518.

Riach, P. A., \& Rich, J. (2004). Deceptive field experiments of discrimination: are they ethical? Kyklos, 57, 457-470.

Rigsby, JT., Addy, N., Herring, C., \& Polledo, D. (2013). An examination of internships and job opportunities. Journal of Applied Business Research, 29, 1131-1143.

Siegel, P., \& Rigsby, J. (1988). The relationship of accounting internships and subsequent professional performance. Issues in Accounting Education, 3, 423-432.

Silva, P., Lopes, B., Costa, M., Melo, AI., Dias, G. P., Brito, E., \& Seabra, D. (2018). The million-dollar question: Can internships boost employment? Studies in Higher Education, 43, 2-21.

Silva, P., Lopes, B., Costa, M., Seabra, D., Melo, AI., Brito, E., \& Dias, G. P. (2016). Stairway to employment? Internships in higher education. Higher Education, 72 $703-721$.

Spence, M. (1973). Job market signaling. Quarterly Journal of Economics, 87, 355-374.

Stigler, GJ. (1962). Information in the labor market. Journal of Political Economy, 70, 94-105.

Stiglitz, J. (1975). The theory of screening, education, and the distribution of income, American Economic Review, 65, 283-300.

Taylor, M. S (1988). Effects of college internships on individual participants. Journal of Applied Psychology, 73, 393-401.

VDAB. (2015). Knelpuntberoepen - kansenberoepen 2015. Brussels: Public Employment Agency of Flanders.

VDAB. (2018). Schoolverlatersrapport 2018. Brussels: VDAB.

Verhaest, D., \& Baert, S. (2018). The effects of workplace learning in higher education on employment and match quality: Is there an early-career trade-off? Empirical Economics, 55, 1229-1270.

Verhaest, D., Bogaert, E., Dereymaeker, J., Mestdagh, L., \& Baert, S. (2018). Do employers prefer overqualified graduates? A field experiment. Industrial Relations, $57,361-388$.

Weiss, F., Klein, M., \& Grauenhorst, T. (2014). The effects of work experience during higher education on labour market entry: Learning by doing or an entry ticket? Work, Employment \& Society, 28, 788-807.

Zopiatis, A. (2007). Hospitality internships in Cyprus: A genuine academic experience or a continuing frustration? International Journal of Contemporary Hospitality Management, 19, 65-77. 